\title{
PRESERVAÇÃO DA ORDEM PÚBLICA: A LEGITIMIDADE DA FORÇA POLICIAL NO COMBATE À VIOLÊNCIA URBANA
}

\section{PRESERVATION OF PUBLIC ORDER: THE FORCE OF LEGITIMATE POLICE IN COMBATING VIOLENCE URBAN}

\author{
Karla Roberta Vasconcelos Costa Lima ${ }^{1}$
}

\section{RESUMO}

Pretende argumentar esta pesquisa sobre a legitimidade na atuação dos atos violentos da atividade policial entre outras questões polêmicas sobre a função e o resultado eficiente na resposta de eventos com imposição de força: crimes em andamento, disparo arma de fogo, condução coercitiva com uso de algema, etc., agem conforme a necessidade para repelir determinadas situações em que se encontram. A prestação do Estado a título de segurança pública visa resguardar a ordem social e a incolumidade de pessoas e bens sob a égide do direito, dos costumes e da discricionariedade da função.

Palavras-chave: Ordem, Legitimidade policial, Violência urbana

\begin{abstract}
Intends to argue that research on the legitimacy of the actions of violent acts of police activity among other controversial issues about the function and efficient outcome in the event of response strongly enforcement: crimes in progress, trigger gun, coercive driving with the use of handcuffs , etc., act as needed to repel certain situations they are in. The provision of the state public security title aims to protect the social order and safety of persons and property, under the aegis of law, customs and the discretion of the function.
\end{abstract}

Keywords: Order, Legitimacy of the police, Urban violence

\footnotetext{
${ }^{1}$ Mestranda em Segurança Pública, Cidadania e Direitos Humanos pela Universidade do Estado do Amazonas - UEA, Manaus, (Brasil). Especialista em Direito Penal e Processual penal pelo Centro Universitário de Ensino Superior do Amazonas. E-mail: karlita.libra@hotmail.com
} 


\section{INTRODUÇÃO}

No Brasil, as causas de crescimento da violência urbana ainda é multidirecional, está associada a processos de desorganização nos grandes centros urbanos, em graus variáveis, ligadas as atividades ilegais. Discursos sociológicos apresentam possíveis causas da violência urbana, tais como a desigualdade social que geram classes segregadas de comportamentos marginalizados, assim como a falta de políticas criminais mais severas, entre outras teorias que tentam explicar o fenômeno da desordem social que põe em evidência os vários tipos de criminalidade.

O Estado democrático de direito regula interesses de ordem pública e privada, assim como intervém em alguns setores como o econômico, cultural e de assistência social; não diferente, os serviços de segurança pública e justiça expressam o exercício de parcela da soberania estatal, na interferência do exercício da liberdade, da propriedade e na manutenção da paz pública.

Desta forma, o Estado intervém no combate a violência urbana, através da atuação das organizações policiais de forma que o indivíduo portador de conduta desviante seja rapidamente reconhecido, capturado e aprisionado, pois se o indivíduo se sobrepõe ao Estado, caminha-se a nação para o desequilíbrio da ordem social.

Mas a repressão policial desestimula o indivíduo a prática de condutas violentas? Seriam as políticas públicas de geração de emprego e distribuição de renda capaz de frear o crescente aumento às praticas violentas que causam tal desordem social?

A sociedade brasileira, de modo geral, tem uma vaga noção entre a violência legal e a violência abusiva existente nas funções oficiais de polícia, cumprimento do dever que traz à discussão o uso necessário da força violenta e o uso aceitável de arma de fogo, além da força física repressiva ou por ameaça.

No exercício da função, o policial mantem-se vigilante às pessoas que não respeitam as regras sociais preestabelecidas, que colocam em perigo a segurança e a paz da coletividade, empregando força violenta, a fim de limitar o progresso do criminoso e combatendo a propagação do crime, e se imprescindível for, atendendo os princípios constitucionais, empreender uma guerra aberta contra a criminalidade. 
Como a sociedade e a mídia articulam a eficácia do trabalho da polícia no combate à violência urbana? As práticas policiais seriam justas ou é apenas uma instituição controladora, sem pretensão maior com a justiça?

A discussão tenta demonstrar como a força policial no uso de ações violentas está socialmente legitimada para atuar com o uso da força violenta sem que pratiquem abuso de autoridade ou crimes comuns. Portanto, uma força pode ser efetiva na prevenção de crimes, outra para controlar tumultos, outra para capturar criminosos, outra para salvar vidas, outra para paralisar ameaça de guerra, entre tantos outros motivos, a maior delas é restabelecer, manter e preservar a ordem pública.

\section{SEGURANÇA PÚBLICA: REPRESSÃO AOS DIREITOS INDIVIDUAIS E GARANTIA AOS DIREITOS COLETIVOS NO COMBATE A VIOLÊNCIA URBANA}

O Estado democrático de direito estabelece regas à vida social, um método de coexistência e cooperação entre os indivíduos membros de uma organização estatal. Sem ordem, a sociedade não poderia possuir nenhum dos outros bens que constitui a justiça; sem ordem, a sociedade viveria em permanente estado de anomia:

O Estado é uma ordem de coação da conduta humana, e logo que se demonstre que esta ordem de coação não pode ser uma ordem diferente da jurídica, porque numa comunidade não há, nem pode haver, mais do que uma só ordem de coação que a constitua, demonstra-se, também, que qualquer manifestação vital do Estado, qualquer "ato estatal", tem que ser um ato jurídico, pois nenhuma ação humana pode ser qualificada de ato estatal senão tendo por base uma norma jurídica, em virtude da qual, por outro lado, se imputa essa ação ao Estado, quer dizer, à unidade da ordem jurídica; e demonstra-se, finalmente, que o Estado, como pessoa, não é mais do que a personificação da ordem jurídica, e que o Estado, como poder, é a eficácia dessa ordem. (MENEZES, 1999, p. 71).

O Estado não pode fazer nada que possa lesar os direitos individuais e liberdades públicas, ou seja, direitos do homem e do cidadão. Tem, pois, o Estado o dever de respeitar a vida, a integridade e prosperidade física, assim como as faculdades intelectuais do ser humano. Tais regras e normas que estabelecem a ordem pública visa entre outros princípios a redução de todo tipo de violência urbana, principalmente as específicas para a redução da violência letal. A prevenção e o controle à violência urbana acende um discurso que mobiliza diversas esferas 
da atuação do poder público na garantia de ambientes mais seguros e uma convivência mais pacífica.

Regulamentar os deveres ou as pressões sociais referenda o reconhecimento de certos valores projetados para transformação da identidade cultural de uma sociedade. Quanto mais a civilização se faça completa, mais o ponto-de-vista jurídico se afirmará. Surge o Estado a partir do momento em que se torne preciso e dominante os interesses comuns. O Estado serve por meio da força como seu elemento político, uma força que dirigirá e sustentará a justiça, como seu elemento jurídico e moral. (MENEZES, 1999, p. 103).

Nota-se que a ideia de Estado, justiça e ordem social são produtos de uma evolução histórica progressiva dos costumes, conjunto de valores que vem se aperfeiçoando através dos tempos.

O Estado, instrumento de domínio público, impõe a sua supremacia através da força, tal força como uso de poder, como imposição de vontades, onde uma maioria é mantida pela disciplina e pela ordem através de certas convenções sociais.

Sob esse entendimento, Paulo Nader (2006), afirma que qualquer fenômeno jurídico que compõe uma identidade cultural se harmoniza com o conceito dialético do fato, valor e norma, também chamada a tríplice teoria do direito do jurista Miguel Reale:

Para Miguel Reale toda experiência jurídica pressupõe sempre três elementos: fato, valor e norma, ou seja, "um elemento de fato, ordenado valorativamente em um processo normativo". O Direito não possui uma estrutura simplesmente factual, como querem os sociólogos; valorativos, como proclamam os idealistas; normativos, como defendem os normativistas. (NADER, 2006, p. 425).

A história da vida humana é escrita por acontecimentos e conforme a aceitação social são ou não legitimados. A tridimensionalidade explica que os fatos geram juízos de valores que demandam normas para regulamentá-los. Portanto, a norma descreve valores que são legítimos na condicionalidade dos fatos sociais e históricos, estes, capazes de revelar as intencionalidades objetivas de um determinado lugar ou época. Através destes fatos em normas que o povo, detentores de determinados valores, ver-se obrigado a praticar condutas que possibilitará a convivência de forma igualitária em sociedade.

Quer dizer, o direito é um elemento normativo que disciplina fatos relacionados ao comportamento individual e coletivo a partir de determinados valores essenciais existentes na ordem natural e social firmada na história da humanidade. Os valores aceitáveis pela sociedade 
(moral), existentes a partir de fatos (acontecimentos sociais), e normatizados a todos como padrão de comportamento social (imposição do Estado aos indivíduos) compõe a ideia da teoria tríplice do direito, onde as experiências do homem são interdependentes a esses três elementos.

Partindo desse entendimento, quando um policial usa de suas atribuições legais para repelir uma injusta agressão ou uma comoção social, a tríplice aliança do direito se estabelece. Quando o agente pratica uma conduta, repressiva ou violenta, mas prevista em determinado tipo penal, lei estadual ou em regimento interno de controle funcional, tal conduta é permissiva no ordenamento jurídico por não ser ilícita ou contrária ao direito e às normas preestabelecidas. O limite da ação policial é a licitude, os excessos terminam onde começa o abuso de poder e o direito deixa de ser exercido para dar lugar a ilicitude.

A existência das forças policiais estão regularizadas no artigo 144 da CF/88, onde assegura o dever do Estado em garantir a segurança pública a toda nação, exercida para a preservação da ordem, da paz e da incolumidade das pessoas e do patrimônio, através dos órgãos que integram o sistema de policiamento nacional: polícia federal; polícia rodoviária federal; polícia ferroviária federal; polícias civis; polícias militares e corpos de bombeiros militares.

A ação policial, essencial para o cumprimento da segurança pública, corresponde a uma convenção social que está legitimada a atos discricionários de atuação por uso de força sistemática no combate a criminalidade. Ressaltando que esta força imposta pelo agente simboliza uma representação impositiva do poder estatal:

A competência exclusiva da polícia é o uso de força física, real ou por ameaça, para afetar o comportamento. A policia se distingue, não pelo uso real da força, mas por possuir autorização para usá-la. Como disse Egon Bittner (1974), "o policial, e apenas o policial, está equipado, autorizado e requisitado para lidar com qualquer exigência para a qual a força deva ser usada para contêla". Mesmo quando não usam da força, ela está por trás de toda interação que acontece (Shearing e Leon, 1975). (BAYLEY, 2006, p. 20).

O agente policial revestido de tal poder defende sua autoridade contra os revoltosos sociais através da dominação por uso de força, seja ela violenta ou não. Para a própria preservação do homem é necessário o embate por meio da resistência, onde o mais forte (representante da ordem) vença o mais fraco (desviante): "mais a força e a liberdade de cada homem, sendo os primeiros instrumentos de sua conservação, como há ele de empenhá-los sem se arruinar e sem olvidar os cuidados que se deve a si mesmo?”. (MENEZES, 1999, p. 88). 
O Estado ao institucionalizar o uso da força para a proteção social, evita que os indivíduos busquem por si mesmos revolver problemas comuns, assim, impõe limite para o agir humano. É uma espécie de pacto coletivo pelo qual o povo, em vista da consecução de finalidades comuns, aceitem normas que regulam relações sociais, neste sentido, torna-se legítima, eventualmente, a violência do Estado.

O fundamento da constitucionalidade de um direito está pautado no reconhecimento de condições que possibilitam a igualdade na liberdade para todos, sem violar princípios basilares como o da segurança pública que devem estar atrelados a outros princípios como o da dignidade da pessoa humana, caso contrário, outros valores, tais como a ordem, a soberania, a democracia, etc., seriam vazios e arbitrários.

A dignidade que integra a estrutura da pessoa humana em suas dimensões de liberdade, autonomia e igualdade de condição na vida social, diz respeito a valorização do homem como homem e do homem como cidadão; assim como, qualquer expressão de violência é um atentado à dignidade humana, como o terrorismo, o genocídio, rebeliões e qualquer outro manifesto desviante são violações aos direitos fundamentais da dignidade da pessoa humana. "Em cada história de assassinato estamos diante da lembrança da violação de uma regra fundamental da civilização" (ROLIM, 2006, p. 187).

O homem necessita se sentir seguro para interagir no meio social; ele quer se sentir seguro ao sair e retornar para a sua casa. A segurança e a sociedade estão intimamente relacionadas já que a segurança foi desde sempre uma necessidade humana (OLIVEIRA, 2006, p. 53). Para isso, o agente policial carrega em si o dever de repelir a violência e a criminalidade porque fundamentalmente deve garantir a segurança da vida e da propriedade:

O conceito de segurança registrou uma evolução significativa do século XVIII para o século XX. No período do Estado absoluto a segurança e a justiça tinham uma dimensão fundamentalmente patrimonial e a responsabilidade pela sua execução competia ao soberano, detentor do poder absoluto. Na fase liberal do Estado constitucional ou de direito o conceito de segurança estava, sobretudo, ligado à proteção da vida e da propriedade e das estruturas do Estado moderno, isto é, da nova ordem pública. O Estado passou a monopolizar a segurança e a servir de intermediário na conflitualidade interpessoal entre os particulares. (OLIVEIRA, 2006, p. 54).

O Estado democrático de direito concede em lei que suas instituições policiais usem a força legalizada, se necessário, dada a situação, não puder ser alcançado de outro modo os rigores da norma constitucional do artigo $144 \mathrm{da} \mathrm{CF} / 88$. A força legalizada deve ser utilizada 
para neutralizar o desviante em ação que caracterize desrespeito às leis, ou que possa causar mal a sociedade.

As forças policiais devem agir sempre de forma defensiva a uma injusta agressão, reagindo de forma proporcional à ação do delinquente de modo a contê-lo imediatamente, por isso, sua reação tem que ser eficaz, proporcional e justificável. Exemplo, o uso do disparo de arma de fogo que só poderá ser feito quando for estritamente inevitável para proteger vidas, inclusive do próprio policial, é uma atuação de medida extrema, regras de último recurso, pois os riscos envolvidos no uso de arma de fogo podem causar danos irreparáveis, ferimentos graves ou até morte:

O uso da força letal com o intuito de atingir os objetivos legítimos de aplicação da lei deve ser considerado uma medida extrema. Os encarregados da aplicação da lei não usarão força letal contra indivíduos, exceto: 1) em casos de legítima defesa ou defesa de outrem contra ameaça iminente de morte ou ferimento grave; 2) para impedir a perpetração de crime particularmente grave que envolva séria ameaça à vida; 3 )efetuar a prisão de alguém que represente tal risco e resista à autoridade, ou para impedir a fuga de alguém que represente tal risco; 4) nos casos em que outros meios menos extremos se revelem insuficientes para atingir tais objetivos. (LIMA, 2011, p. 22).

A violência urbana é um fato social, não normatizado que fere valores morais; a violência por meio da força policial é um fato social, normatizado que integra os valores morais de um Estado democrático de direito. Quando um policial efetua disparos de arma de fogo no estrito cumprimento do dever legal ou agindo em legítima defesa própria ou de terceiros, esta prática não deixa de ser violenta, porém, está revestida de legitimidade na proporcionalidade de sua ação e na necessidade de sua realização.

No exercício da função, o agente policial mantem-se vigilante às pessoas que não respeitam as regras sociais preestabelecidas, que colocam em perigo a segurança e a paz da coletividade, a fim de manter o controle social:

Mas controle social é um conceito que não soa bem aos ouvidos mais liberais. Isso ocorre porque, em suas origens, ele relacionava-se ao controle do comportamento desviante. Para Donald Black "controle social é o aspecto normativo da vida social; ou a definição de um comportamento desviante e a resposta a ele, tais como proibições, acusações, punições e compensação". Trata-se de uma concepção repressiva por definição, pois visa regular e enquadrar condutas de pessoas que por algum motivo são definidas como desviantes. (BEATO FILHO, 2012, p. 38). 
É possível garantir o controle social no combate à violência urbana sem o uso da violência por parte das forças repressivas que o Sistema de Segurança Pública disponibiliza? A violência urbana é uma estratégia de sobrevivência dos segregados ou uma desordem social de condutas desviantes? As instituições policiais poderiam influenciar na ideologia de um sistema de controle criminal perfeito? A criminalidade, a polícia e a sociedade estão sob o domínio de políticas públicas e estas estão longe de responderem tais questionamentos.

Entretanto, questões relacionadas à violência urbana e a atuação das organizações policiais sustentam recorrentes pautas dos meios de comunicação, permeando sentimento generalizado de insegurança e medo do sistema de segurança pública existe no Brasil. Assim como, a divulgação de imagens sangrentas relacionadas à criminalidade e a ação policial choca o senso comum e causa desconforto nas autoridades representativas do sistema.

As manchetes em pauta nos meios de comunicação "está comprometida com o discurso de que o crime está fora de controle e que a violência cresce de forma assustadora”. (ROLIM, 2006, p. 191). Na verdade, a aceitação da força policial reflete uma intolerância crescente à desordem popular na vida urbana, injustiças sumárias nas ruas manifestas pelas classes consideradas perigosas, desviantes:

Protesto contra tarifa em São Paulo afeta metrô e tem tumulto no fim. O quarto protesto do MPL (movimento passe livre) contra a alta das tarifas do transporte causou nesta terca (19) o fechamento de comércios e estações de metrô e terminou com episódios pontuais de vandalismo no centro. No fim do ato, por volta das $22 \mathrm{~h}$, quando a maioria dos manifestantes havia ido embora, uma agência bancária foi depredada na rua Barão de Itapetininga e um grupo que participava do ato colocou fogo em lixeiras na rua Sete de Abril. Ativistas tentaram pular as catracas na estação República do metrô e bloquear a avenida Ipiranga e foram impedidos. A PM usou bombas no fim do protesto em ao menos duas ocasiões (...) (FOLHA DE S.PAULO, 20/01/2016)

Ações violentas estão em todo lugar e são corriqueiramente manchetes de jornais escritos e eletrônicos: roubos, homicídios, vandalismos, acidentes de transito, latrocínio, entre outros crimes violentos ou os categorizados como delitos contra a propriedade, são cenários que mais causam impacto nas notícias veiculadas aos meios de comunicação e, a atuação

\footnotetext{
${ }^{2} \mathrm{O}$ uso da violência causa medo e sensação de insegurança na população que está como espectadora dos dois lados da violência: policial e urbana. O Estado de São Paulo e a cidade são substancialmente violentas, e mesmo havendo uma redução da desordem social que gera a criminalidade, elas continuariam marcadas pela violência nas condições socioeconômica. Disponível em: http://www1.folha.uol.com.br/cotidiano/2016/01/1731402-protestocontra-tarifa-em-sao-paulo-afeta-metro-e-tem-tumulto-no-fim.shtml. Acesso em: 05/05/2016.
} 
policial, na maioria das vezes, é a protagonista dos holofotes das mídias sensacionalistas. "Diante do crime a mídia é sensacionalista" (ROLIM, 2006, p. 192).

Seja nos erros ou acertos, a divulgação da ação policial no uso de força violenta causa desgaste na confiança do público e constrangimento dos policiais dentro da própria instituição.

A população é influenciada pelas notícias divulgadas nas mídias que consequentemente são propagadas pelas redes sociais e já se imaginam vitimas dessa recorrente violência tanto praticada por policiais quanto por criminosos, repercutindo a sensação de insegurança:

Ocorre que essa maneira de tratar a criminalidade e a violência termina por construir uma "realidade invertida". Sabe-se que a atenção da mídia ao crime é dirigida para a violência, notadamente para os casos de homicídios. Há, também, consenso entre pesquisadores de que alguns homicídios atraem mais a atenção da mídia. Histórias com maior número de vítimas ganham mais destaque. O número de agressores e o uso de métodos não comuns são outros fatores que podem "projetar" um caso. (ROLIM, 2006, p. 193)

A influência da mídia na formação de opinião negativa na atuação da polícia é em alguns casos condenável do ponto de vista conceitual, sensacionaliza a criminalidade e desenvolve na população uma sensação de insegurança e medo. $\mathrm{O}$ clima de medo e insegurança deixa os cidadãos vulneráveis a conceitos equivocados e oportunistas:

A mídia, comumente se encarrega de amplificar e retroalimentar o medo. O crime rende boas manchetes, o medo do crime vende jornais e encontra ampla audiência - da mesma forma que, cada vez mais, o medo do crime rende bons negócios (de carros de passeio blindados a armas, de "condomínios exclusivos" aos serviços de firmas de segurança particular) e promete render votos a candidatos a cargos no Executivo e no Legislativo. (SOUZA, 2008, p. $30)$.

Eventos que causam tumultos e excesso de vandalismo são eventos críticos que acontecem provocados por pessoas ou grupos que querem mudanças político-sociais com ameaças ou uso de violência, apesar do pleito ser embasado em garantia aos direitos civis e amparados pela Constituição, não são legitimados pois a forma desordeira como se manifestam banaliza a busca de tais conquistas, daí a forma ostensiva da força policial durante um evento crítico que é preservar a ordem, bens materiais e físicos.

Não obstante, o modo do crime repercuta um problema psicossocial. Uma pessoa pode nunca ter visto ou vivenciado qualquer ato praticado por policiais no uso de força violenta, mas a constante divulgação nos meios de comunicação faz da violência um elemento cotidiano desta 
classe de servidores públicos, desta forma, o fenômeno do medo e da sensação de insegurança é mais de mera opinião do que de experiências pessoais.

Mas como explicar a violência de uso da força policial sendo formalmente válida? A validade se positiva na sua eficácia, pois a ordem social estabelecida, o Estado cumpre o papel de tutor do povo, impondo a sua soberania através da atuação de seus agentes públicos e isso, contém sempre certa dose de justiça e esta é intransponível.

A conduta do agente pode consistir num fazer ou deixar de fazer alguma coisa sempre tendendo evitar um mal maior. Quando ele usa bomba de efeito moral, age no dever de paralisar um tumulto, a fim de evitar um resultado ainda mais gravoso, onde várias vidas podem estar com sua integridade física em risco. As práticas policiais violentas desde que esteja dentro dos limites impostos pelas leis, previstas para coagir determinada modalidade de violência urbana, encontra amparo nas causas de excludente de ilicitude, apenas os excessos são puníveis pelo abuso de poder.

Assim como há os deveres fundados na função pública, deveres de conteúdo moral: ser honesto, de modo a dignificar a instituição que serve e a sua imagem particular; respeitar os direitos e as garantias individuais no trato com os delinquentes; não praticar delitos, mas preservar a ordem observando o interesse público; prestar socorro à pessoa que necessita, ante o perigo e o abuso; respeitar direito alheio, a moral social e os bons costumes. O que é moralmente bom é indispensável porque é um dever de acordo com a lei natural do homem.

A eficiência do serviço na prevenção e repressão a criminalidade articula-se através de expressões corporais e armamentos permissivos. O poder estatal regula o corpo e o ato do cidadão, além do espaço territorial em que habita, daí a administração pública autorizar o uso de força para cuidar de assuntos que são essenciais e fundamentais para a coletividade:

Para Bayley, o caráter dos regimes (totalitário e/ou democrático) afeta o funcionamento policial com relação à centralização do comando policial e a extensão da interferência policial na vida política. Contudo o caráter dos regimes não afeta a natureza das tarefas desempenhadas pela polícia, com exceção daquelas ligadas à polícia. $\mathrm{E}$ também não afeta o número de forças sobrepostas que a comunidade possui nem os mecanismos pelos quais a responsabilização policial é alcançada. Pelo contrário, a polícia afeta o tipo de governo que a comunidade possui. A repressão policial é vista como a repressão do regime político. Mas o comportamento policial tem consequências políticas independentes. As ações policiais independentes afetam criticamente a competição política e moldam os processos sociais que, por sua vez, afetam a vida política. (RIBEIRO, 2002, p. 451). 
A finalidade da preservação da ordem pública autoriza limitar o livre-arbítrio do cidadão na contenção de atividades particulares antissociais, prejudiciais à segurança pública, sem que configure constrangimento ilegal, pois a liberdade individual não pode estar acima da lei. Por isso os agentes policiais necessitam de certa autonomia para poder alcançar seus objetivos e realizar suas funções, encontram-se legitimados a empregarem a força violenta e o uso de arma de fogo quando necessário.

Quando o agente repele uma conduta arbitrária, está preservando o direito da sociedade: repele-se o direito individual em prol do direito da coletividade; valoração da democracia e enfraquecimento da anarquia.

A resposta do agir com uso de força deve ser justificado pelo "dever agir", sendo aquela obrigação derivada de lei, a chamada obrigação legal. Desta Forma, Bayley entende que definir o trabalho policial não é questão simples: "O trabalho policial pode se referir, primeiramente, ao que a polícia é designada para fazer; segundo, a situações com as quais ela tem que lidar; terceiro, às ações que ela deve tomar ao lidar com as situações”. (BAYLEY, 2006, p. 118). A maneira como agir diante de um crime concreto depende da classificação dos fatos de acordo com o grau atribuído aos participantes da ocorrência.

A violência urbana é um problema social (desfavorecimento econômico de algumas classes sociais) ou institucional (falta de política legislativa do sistema penal)? Para Beato Filho, esse problema se confunde na medida em que tal problema está vinculado a questões relativas a ordem e a ação, a aplicação das leis como regras de decisão da qual podemos inferir as condições de seu uso por atores sociais:

Convencionalmente, a sociedade é concebida como um fenômeno que emerge da implementação de obrigações coletivas por parte de seus membros. Assim, a adesão individual ao conjunto de normas e valores da sociedade se dá através de processos de socializações bem-sucedidas em torno de uma cultura normativa que ordena comportamentos individuais de acordo com interesses da sociedade. Por outro lado, as regras e normas obrigatórias, legalmente definidas, determinam condutas individuais através de sistemas de sanções e controle social. (BEATO FILHO, 2012, p. 28).

Não resta dúvida que o controle social é a base cognitiva para muitas das concepções que visam restringir a violência urbana, tais como reformas nas organizações da justiça criminal: policiamento mais capacitado e presente nas ruas, tribunais mais céleres nos julgamentos, legislações penais mais severas e maior número de prisões em todos os estados, entre outros. 
O capitalismo concentra riquezas nas mãos de poucos em detrimento e prejuízo da imensa maioria. Mas para Yves Pedrazzini, os países de terceiro mundo patinam na ausência atuante do poder público, não há estruturas consolidadas no combate a criminalidade, portanto, não há como paralisar a violência urbana, esta, porém, não é um fenômeno relacionado apenas a pobreza:

A violência urbana não é um fenômeno isolado: a urbanização caótica, a densificação ou a privatização dos espaços públicos, a segregação social e racial leva a considerar as atividades informais e ilegais, violentas ou não, como indicadores de uma transformação mundial da civilização urbana. A informalização da urbanização é uma resposta das populações carentes à globalização e às políticas de segurança, na medida dos seus meios. (PEDRAZZINI, 2006, p. 23).

As reformas políticas pouco observam fatores na perspectiva de uma teoria macrossocial da violência urbana que predispõe ao crime: concentração da pobreza, declínio do capital social e, sobretudo, desorganização da própria administração pública. O Estado, com o aumento do crime organizado por facções que fincaram forças nas ruas, nos presídios, nas próprias organizações estatais, mostra-se vulnerável no combate a criminalidade.

Percebe-se que as facções criminosas como o PCC (primeiro comando da capital), CV (comando vermelho), FDN (Família do Norte), entre outras, são organizações que comandam rebeliões, assaltos a bancos, sequestros, execuções humanas e narcotráfico no Brasil, e em outros países da América do Sul, como a Bolívia e o Paraguai. São organizações financiadas pelo tráfico e pelos roubos a mão armada. No Brasil, estas facções, principalmente o PCC, já se espalharam por alguns territórios. Nos dias atuais várias membros destas facções cumprem pena no sistema penitenciário, e mesmo assim, conseguem dominar o crime organizado fora das prisões, causando pavor e desequilíbrio na ordem social.

Não resta dúvida que as causas da criminalidade movimentada pelo crime organizado tem um pano de fundo eminentemente econômico, assim como os gastos em serviços decorrentes da violência causam prejuízos ao desenvolvimento socioeconômico do país:

Se tomados os diversos gastos com a violência, teremos o expressivo valor de $\mathrm{R} \$ 92,2$ bilhões, correspondente a 5,09\% do PIB no ano de 2004, o que significa um gasto de 519,40 por habitante. Os gastos maiores do setor público foram com o Sistema de Segurança Pública $(1,45 \%)$, que inclui a manutenção das polícias. O sistema prisional também contribui com parcela significativa $(0,15 \%)$, seguindo impacto no Sistema de Saúde $(0.06 \%)$. Os maiores custos recaíram sobre o setor privado, que arcou com perdas de capital humano em 
$1,35 \%$. Segurança privada, seguros e transferências por roubos e furtos compõem o total de $2,08 \%$, totalizando $3,43 \%$ de perdas para o setor privado. (BEATO FILHO, 2012, p. 116).

Mas o Sistema de Segurança Pública do Brasil está capacitado para combater o crime face às causas de sua origem, proliferação da miséria e propagação do domínio faccioso sob o poder público? Provavelmente não, enquanto os problemas de segurança pública estiverem engessados aos déficits sociais: socioeconômico e macroestrutural.

Sociólogos e reformadores sociais voltados às ciências criminais afirmam que a criminalidade irá aumentar no decorrer dos próximos anos, portando, haverá necessidade do aumento de políticas públicas sociais e melhor capacitação dos agentes policiais. O volume de crimes irá aumentar bem como o colapso da disciplina informal nos grupos sociais tradicionais, especialmente nos países que se estão modernizando rapidamente. Como resultado, os policiais na rua crescerão. (RIBEIRO, 2002, p. 452).

A tutela do Estado em proteger pessoas e bens patrimoniais refere-se à preservação da paz social, onde a sociedade se sinta segura de interferências não justificadas. Quando a justiça e a segurança pública não atendem aos padrões necessários e desejados pela população, surge nova instituição de controle, chamada de segurança privada ou policiamento privado, como assegura Bayley:

Para a grande maioria das pessoas, as forças policiais mais autoritárias e importantes em suas vidas são aquelas públicas, especializadas, e profissionais. Essas três características são quase um sinônimo de policiamento moderno - quase, porque o policiamento privado vem se expandindo tão rapidamente que em alguns países seus membros são tão numerosos quanto os da polícia pública. (BAYLEY, 2006, p. 23).

$\mathrm{Na}$ ausência de um Estado suficientemente forte para prover esta paz, surgem novas entidades corporativas privadas que descentralizam o poder estatal, exemplo claro é da segurança privada que favorece a proteção de bem físico e material, porém, não podem ser vistos como órgãos de lei e ordem previstos pela Constituição Federal.

A segurança privada usurpa do Estado o poder de ser a única instituição capaz de criar uma força policial. A segurança privada é aquela não mantida pelos cofres públicos e o âmbito de sua atuação não alcança a todos da sociedade, apenas a parcela que paga individualmente pelos seus serviços. 
A segurança privada é uma atividade econômica que em regra, presta serviço de proteção ao patrimônio e a vigilância de pessoas. No Brasil, esta atividade é um ofício que vem crescendo em decorrência da sensação do aumento de criminalidade, tal serviço está muito presente nos bancos, nos shoppings centers, nos condomínios residenciais e até em escolas e faculdades particulares.

A segurança privada está disposta pela Lei $\mathrm{n}^{\circ}$. 7.102/1983, que dispõe sobre segurança para estabelecimentos financeiros, estabelece normas para constituição e funcionamento das empresas particulares que exploram serviços de vigilância e de transporte de valores;

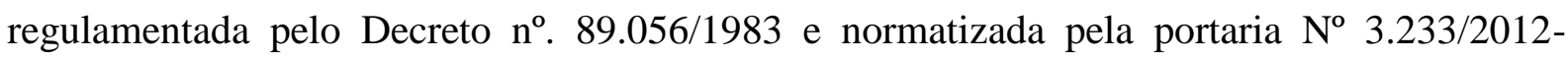
DG/DPF, de 10 de dezembro de 2012. Essa atividade deve ser regulada, autorizada e fiscalizada pelo Departamento da Polícia Federal.

Também denominada em alguns lugares de "vigilância patrimonial", a segurança privada tem seus limites de atuação nas dependências do estabelecimento a ser protegido conforme estabelecido em contrato, mas sempre dentro de espaços privados. Caso ocorra os excessos que cause danos lesivos a imagem e a condição física, a responsabilidade será da empresa contratada, responsável por eventuais falhas ocasionadas pelos agentes de segurança.

Portanto, enquanto o policiamento público age no interesse público, o "policiamento privado" ou a segurança privada, quase sempre, age em desacordo com este, pois a segurança privada aumenta a sensação de insegurança, acentua a ideia de um Estado não atuante quanto garantidor da segurança nacional, no entanto, ela é uma resposta a esse sentimento de insegurança que se alastra a cada dia:

No entanto é o desenvolvimento do policiamento privado que vai aumentar a segurança num futuro próximo. $\mathrm{O}$ policiamento cresceu, mas não o policiamento público, afirma Bayley. O policiamento privado representa a mobilização da comunidade sob os auspícios do mercado. Pode ser a maneira de as sociedades democráticas resolverem a preservação do crime, evitando desencorajar a penetração policial formal na comunidade. (RIBEIRO, 2002, p. 453).

Mas a segurança privada como está legitimada aqui no Brasil, teria a mesma legitimidade do policiamento público ao fazer uso da força violenta no exercício de suas atribuições? Em regra a resposta é não, ela é uma entidade paga para proteger interesses econômicos, proteção da propriedade de seus empregadores, contra furtos, vandalismos e outros. 
O perigo desse trabalho administrado por particulares está no exceder os limites de competência da segurança pública. Quando a segurança privada faz uso das forças armadas as consequências ameaçam seriamente os direitos civis e ao sistema de segurança pública tutelado pelo Estado, pois fere a segurança das bases democráticas.

Portanto, enquanto não houver políticas públicas de ações assistencialistas garantindo os direitos fundamentais do cidadão, ou melhor, enquanto não houve plano de combate aos problemas sociais, tais como: combate a pobreza e ao declínio do capital social, haverá criminalidade e violência na perspectiva de uma teoria macrossocial da criminalidade e da violência, o interesse recai sobre os fatos de risco que predispõem ao crime (BEATO FILHO, 2012, p. 48).

O uso da força violenta na preservação da ordem pública, só terá fim quando o controle social for a base cognitiva das concepções de controle à criminalidade e desordem pública. "Os excluídos são os protagonistas da violência, mas não são os únicos responsáveis por ela". (PEDRAZZINI, 2006, p. 26). A pobreza e o desemprego não são as únicas expressões da violência urbana, mas sim, uma patologia social que se manifesta através da criminalidade.

$\mathrm{Na}$ verdade, o sistema penal aproveita as demandas sociais para se legitimar, seja pela opinião publica, seja pelos mecanismos jurídicos, seja pelas instituições que compõem o sistema de segurança pública, enfim, seja qual for a causa, os fatores que fundamentam o sistema penal brasileiro é o agente policial que protege os interesses mais importantes da vida social dando cumprimento a lei e a ordem na preservação dos interesses públicos.

\section{CONCLUSÃO}

Os elementos fáticos, axiológicos e normativos referem-se a uma série de relações sociais de objetivos organizacionais e estruturais incorporados nas instituições do sistema de justiça criminal. A criação de uma norma que visa regulamentar condutas individuais em medidas coletivas para o bem comum de uma sociedade dar-se através de atos próprios do poder Estatal, nesse contexto, as demandas sociais e o poder estatal se ajustam intervindo no combate a questões de desordem pública.

A norma que impõe o dever do Estado de fornecer serviços de segurança pública no combate à violência urbana tem validade formal e material porque obedece as condições de competência e legalidade. $\mathrm{O}$ artigo $144, \S 7^{\circ}, \mathrm{CF} / 88$, atribui competência ao legislador sobre a 
organização e funcionamento dos órgãos de segurança pública, impossibilidade o próprio Estado de evitar tal cumprimento. As organizações policiais executam exercícios próprios de soberania estatal pelo uso de força violenta simbólica, entre outros atributos.

Porém, as evidências mostram que o Estado não tem proporcionado condições satisfatórias e dignas no respeito aos direitos civis da população brasileira. Falta qualidade na prestação de serviços públicos: educação, saúde, emprego, moradia, segurança, além de implementações de projetos sociais para a erradicação da pobreza. Tais deficiências básicas refletem no insucesso da prevenção de delitos e controle da ordem social.

A polícia desencoraja o criminoso em sua ação, mas não pode agir fazendo justiça com as próprias mãos, não possui qualquer poder jurisdicional, não pode julgar e punir o infrator, tarefa esta, restrita do poder judiciário, órgão que compete esclarecer e julgar a verdade dos fatos e aplicar a justa punição. A vingança ou o abuso de poder são causas de excesso de atribuição.

A realidade e a significação entre "dever" e "fazer" no uso de força violenta só se justifica à luz de uma concepção sistemática dos fenômenos social, entre a vontade da sociedade e a validez concreta dessas vontades. Ao que parece, só há a constituição organizacional de uma sociedade civil quando o interesse, a necessidade e a violência são depurados e regularizados pelo Estado.

Podemos dizer que nos dias atuais há uma concordância quanto à complexidade do fenômeno da violência urbana, isto é, se antes as soluções ancoravam-se fundamentalmente no sistema de justiça criminal: policiais civis, militares, Ministério Público, Juízes e o sistema prisional; atualmente, um novo referencial se faz claro, apontando situações que demandam outras intervenções que não somente aquelas de caráter repressivo, mas também de investimento em ações preventivas, cujas esferas de atuação transbordam os limites de forças policiais e de justiça, mas sim, de medidas políticas que o Estado poderia desenvolver no sentido de minimizar as desigualdades sociais, tais como a hiperurbanização responsável pela miséria nas grandes cidades.

Há uma relação entre o crescimento dessa população rural que migram para os grandes centros urbanos e o aumento da criminalidade, fenômenos sociais que se evidenciam tanto na mídia como nos estudos de caráter científico. Descentralizados os pólos industriais, as classes menos favorecidas passam a engrossar as fileiras de marginalizados que vivem sob constante vigilância policial e que a cada instante, tornam-se alvos das organizações criminosas. 
A violência urbana só terá fim, com fim da exclusão social que violenta a maior parte da população brasileira. Reforma agrária, reforma urbana, políticas de emprego e moradia, equiparações salariais, sistema de saúde pública eficaz, sistema de ensino profissionalizante voltado aos jovens, combate a miséria, entre outras estruturas sociais necessárias para a garantia dos direitos civis.

O serviço de segurança pública é uma atividade exclusiva do poder estatal (Emenda Constitucional $n^{\circ}$. 19/1998). Os sistemas de segurança particular ou privada são atividades acessórias, subsidiárias às organizações policiais, não substituem nem preenchem as funções do serviço público. O policiamento privado não é uma entidade guardiã da lei e quando ela expande a sua atividade fazendo uso de força violenta a sua função é apenas uma expressão de autodefesa e autoajuda.

O policiamento é um monopólio estatal, legítimo em sua manifestação pública e, o poder público tem o dever de prestar serviços de segurança de forma eficiente, atendendo às necessidades de todas as classes sociais, seja pobre ou rica, a sociedade tem o direito de receber do Estado serviços de segurança pública com o uso de razoabilidade e proporcionalidade desses direitos.

\section{REFERÊNCIAS}

ADORNO, Sérgio. Violência, controle social e cidadania: dilemas da administração da Justiça Criminal no Brasil. Revista Crítica de Ciências Sociais, n.41, p.101-127, dez. 1994.

BAYLEY, David H. Padrões de Policiamento: uma Análise Internacional Comparativa. São Paulo: Editora da Universidade de São Paulo, 2006.

BEATO FILHO, Claudio Chaves. Crime e Cidades. Belo Horizonte: Ed.UFMG, 2012.

BITENCOURT, Cezar Roberto. Manual de Direito Penal - Parte Geral. São Paulo: Saraiva, 2000, Vol. I.

HOLlOWAY, Thomas H. Polícia no Rio de Janeiro: repressão e resistência numa cidade do século XIX. Tradução de Francisco de Castro Azevedo. Rio de Janeiro: FGV, 1997. 
LIMA, João Cavalim de. Atividade Policial e o Confronto Armado. Curitiba: Juruá, 2011.

MENEZES, Anderson de. Teoria Geral do Estado. Rio de Janeiro: Forense, 1999.

NADER, Paulo. Introdução ao Estudo do Direito. Rio de Janeiro: Forense, 2006.

OLIVEIRA, José Ferreira. As políticas de segurança e os modelos de policiamento: A emergência do policiamento de proximidade. Coimbra: Almedina, 2006.

PEDRAZZINI, Yves. A violência das cidades. Petrópolis, RJ: Vozes, 2006

REIS, Freide. Ciência do Direito, norma, interpretação e hermenêutica jurídica. Rio de Janeiro: Forense Universitária, 2006.

RIBEIRO, Iselda Corrêa. Polícia. Tem futuro? Polícia e sociedade em David Bayley. Disponível em: http://www.scielo.br/scielo.php?script=sci_arttext\&pid=S151745222002000200017. Acesso em: 29/04/2016.

ROLIM, Marcos. A síndrome da rainha vermelha: policiamento e segurança pública no século XXI. Rio de Janeiro: Zahar; Oxford, Inglaterra: University of Oxfor, Centre for Brazilian Studies, 2006.

RODRIGUES, Artur; BERGAMIM JR, Giba e MACHADO, Leandro. Protesto contra tarifa em São Paulo afeta metrô e tem tumulto no fim. Disponível em: http://www1.folha.uol.com.br/cotidiano/2016/01/1731402-protesto-contra-tarifa-em-sao-pauloafeta-metro-e-tem-tumulto-no-fim.shtml. Acesso em: 05/05/2016.

SOUZA, Marcelo Lopes de. Fobópole: o medo generalizado e militarização da questão urbana. Rio de Janeiro: Bertrand Brasil, 2008.

SANTIN, Valter Foleto. Controle Judicial da Segurança Pública: Eficiência do serviço na prevenção e repressão ao crime. São Paulo: Editora Revista dos Tribunais, 2004. 